Article

\title{
A New Tool in the Quest for Biocompatible Phthalocyanines: Palladium Catalyzed Aminocarbonylation for Amide Substituted Phthalonitriles and Illustrative Phthalocyanines Thereof
}

\author{
Vanessa A. Tomé, Mário J. F. Calvete* ${ }^{*}$, Carolina S. Vinagreiro $\mathbb{D}$, Rafael T. Aroso and \\ Mariette M. Pereira * \\ Centro de Química de Coimbra (CQC), Department of Chemistry, University of Coimbra, \\ Coimbra 3004-535, Portugal; vanessalmeida_97@hotmail.com (V.A.T.); \\ carolina_svinagreiro@hotmail.com (C.S.V.); fortilap@gmail.com (R.T.A.) \\ * Correspondence: mcalvete@qui.uc.pt (M.J.F.C.); mmpereira@qui.uc.pt (M.M.P.); \\ Tel.: +351-966-174744 (M.J.F.C.); +351-239-854474 (M.M.P.)
}

Received: 1 October 2018; Accepted: 17 October 2018; Published: 20 October 2018

\begin{abstract}
The amide peptide bond type linkage is one of the most natural conjugations available, present in many biological synthons and pharmaceutical drugs. Hence, aiming the direct conjugation of potentially biologically active compounds to phthalocyanines, herein we disclose a new strategy for direct modulation of phthalonitriles, inspired by an attractive synthetic strategy for the preparation of carboxamides based on palladium-catalyzed aminocarbonylation of aryl halides in the presence of carbon monoxide (CO) which, to our knowledge, has never been used to prepare amide-substituted phthalonitriles, the natural precursors for the synthesis of phthalocyanines. Some examples of phthalocyanines prepared thereof are also reported, along with their full spectroscopic characterization and photophysical properties initial assessment.
\end{abstract}

Keywords: peptide bond; phthalonitriles; phthalocyanines; aminocarbonylation; palladium catalysts

\section{Introduction}

Molecules of the tetrapyrrole family (e.g., porphyrin and phthalocyanine derivatives) are probably the most appealing chromophores for a vast array of photoactivated processes, such as phototherapy [1-3], photodiagnosis [4-6], photocatalysis [7,8], solar energy conversion [9,10], and also as photomaterials [11-13]. In particular, phthalocyanines largely fulfil a crucial optical requisite, necessary for photomedicinal applications, which is a strong absorption in near-infrared (NIR) spectral region (600-900 nm), as light in this region affords the deepest penetration in soft tissue. These highly stable compounds, possessing high molar absorptivity, high quantum yields of fluorescence and structural versatility $[4,13,14]$, can be conveniently modified to grant suitable biological solubility [15-18], by introduction of hydrophilic moieties in the structure. The majority of the moieties used so far are negatively charged, such as sulfonates or carboxylates [15,19] or positively charged, like quaternized amines $[15,20]$. These ionic features present some important drawbacks like low cellular uptake and/or cellular internalization, due to the negatively-charged character of the cell plasma membranes, in the case of anionic phthalocyanines [21], or exaggerated phospholipid affinity, leading to phospholipidosis, in the case of cationic phthalocyanines [22]. Thus, in the search for biocompatibility, the amide peptide bond type linkage is one of the most natural conjugations available, present in many biological synthons, such as peptides, proteins, or amino acids [23], as well in 
pharmaceutical drugs [24,25]. Nevertheless, amide-substituted phthalocyanines are rare [26-35], when compared with other functionalities, including a few reports of phthalocyanines conjugated with amino acids [27-30] and peptides [31-35]. The main reason for the scarcity in phthalocyanine-amino acid conjugates arises from the difficult synthetic manipulation, which relies in troublesome transformations and purification procedures using highly polluting chemicals $[25,27-30,36,37]$.

Apparently, phthalocyanine post-synthetic modulation would not be a very straightforward option, due to the chemical stability owned by phthalocyanines, which are quite stable against this type of structural variation. On the other hand, modification of precursory phthalonitriles bearing carboxylic acids is also demanding, given the sensitiveness of nitrile functions. It is worth mentioning that we have tested the strategies ourselves, to explain our points, and results were as described in the text. Whether in case of post-synthetic phthalocyanine modification or phthalonitrile modulation, no reproducible results could be obtained, always leading to cumbersome work-up approaches.

Palladium-catalyzed carbonylation reactions were first described by Heck almost 40 years ago [38]. Since then, many developments have been reported [6,39-46] and nowadays carbonylation has become an indispensable alternative to the classic organic synthesis of carbonyl compounds, including carboxylic acid derivatives (e.g., amides, esters) with valuable application in both industrial and fine chemistry. Among these reactions, aminocarbonylation [47-50], carried out using Ar-X substrates ( $\mathrm{X}=\mathrm{I}, \mathrm{Br}, \mathrm{Cl}$, OTf, OTs, etc.), in the presence of $N$-nucleophiles, emerges as a sustainable, one-step synthetic approach, for the efficient, selective and mild synthesis of amides.

Herein we disclose a new strategy for direct modulation of phthalonitriles, inspired by an attractive synthetic strategy for the preparation of carboxamides based on optimized palladium-catalyzed aminocarbonylation of aryl halides in the presence of carbon monoxide (CO) [38,51] which, to our knowledge, has never been used to prepare amide-substituted phthalonitriles, the natural precursors for the synthesis of phthalocyanines. Furthermore, transformation thereof to the desired phthalocyanines is also described.

\section{Results and Discussion}

Modification of phthalonitriles is usually the chosen methodology when attempting to introduce significant changes at the phthalocyanine periphery, instead of phthalocyanine post-synthetic modulation [52], due to the known chemical stability owned by phthalocyanines. A conceivable example would be, for instance, to synthesize a phthalocyanine bearing peripheral four carboxylic acid groups, followed by acyl chloride formation, using a hazardous chlorinating agent, and then functionalization with an amine. The main issue regarding this strategy would be the proneness to form mixtures of mono-, di-, tri-, and tetra-amide substituted phthalocyanines requiring the use of excessive amounts of nucleophile, giving raise to cumbersome purification and low yields.

Our herein envisaged strategy uses 4-iodophthalonitrile (1) [53] as substrate and a range of amines as nucleophiles, in presence of a palladium catalyst formed in situ by addition of palladium(II) acetate to triphenylphosphine (in 1:2 molar ratio), together with $\mathrm{Et}_{3} \mathrm{~N}$ as base and carbon monoxide as reagent (Table 1) [54,55]. Our studies began with the aminocarbonylation of 4-iodophthalonitrile (1) using glycine methyl ester hydrochloride (2a) as model nucleophile, to optimize reaction conditions (temperature, pressure of $\mathrm{CO}$ and time reaction parameters) in the palladium-catalyzed aminocarbonylation reaction (Table 1).

The first reaction conditions employed $\left(\mathrm{P}_{\mathrm{CO}}=10\right.$ bar and $\left.\mathrm{T}=65^{\circ} \mathrm{C}\right)($ Table 1 , entry 1$)$ afforded only $25 \%$ substrate conversion, after $24 \mathrm{~h}$. Then, we investigated the effect of increasing temperature, keeping the $\mathrm{CO}$ pressure at $10 \mathrm{bar}$, and it was found that, at $85^{\circ} \mathrm{C}$, the reaction proceeded faster, and full conversion of substrate 1 within $24 \mathrm{~h}$ was obtained (Table 1, entry 2). Keeping CO pressure at 10 bar and temperature at $85^{\circ} \mathrm{C}$, the reaction was not complete when reaction time was decreased to $12 \mathrm{~h}$, reaching only $70 \%$ conversion of $\mathbf{1}$ (Table 1 , entry 3 ). Conversely, when the reaction temperature was increased to $100{ }^{\circ} \mathrm{C}$, keeping the pressure at 10 bar and reaction time at $12 \mathrm{~h}$, substrate 1 was totally transformed into the desired amide (Table 1, entry 4 ). In addition, when the CO pressure was 
reduced to 5 bar, keeping the temperature at $100^{\circ} \mathrm{C}$, after $12 \mathrm{~h}$, the conversion of substrate 1 was $>97 \%$ (Table 1, entry 5). However, keeping CO pressure at 5 bar and reducing the temperature to $65^{\circ} \mathrm{C}$, it required $70 \mathrm{~h}$ until full conversion of substrate 1 was observed (Table 1, entry 6). Thus, this indicates that the temperature plays the most important role on the activity of the catalyst. To evaluate the effect of solvent, an additional experiment was performed using DMF instead of toluene and, regardless of the high conversion obtained using the same conditions, this reaction yielded a complex mixture of products (Table 1, entry 7), as checked and compared using thin layer chromatography-TLC, which may be attributed to decomposition of DMF. Summing, it was found that a temperature of $100{ }^{\circ} \mathrm{C}$, a CO pressure of 5 bar and a reaction time of $12 \mathrm{~h}$ were the optimal reaction parameters selected to extend the scope of 4-iodophthalonitrile functionalization.

Table 1. Optimization of reaction conditions ${ }^{a}$.

\begin{tabular}{|c|c|c|c|c|c|}
\hline $\mathrm{N}$ & 1 & $\mathrm{H}_{\mathbf{2 a}} \prod_{\mathrm{O}}^{\mathrm{OMe}}$ & $\frac{\mathrm{Pd}(\mathrm{OAc})_{2,} \mathrm{PPh}_{3}}{\text { Toluene, } \mathrm{NEt}_{3}}$ & $\mathrm{NC}^{-}$ & nain product) \\
\hline Entry & Solvent & CO Pressure (bar) & Temperature $\left({ }^{\circ} \mathrm{C}\right)$ & Time (h) & Conversion $(\%)^{b}$ \\
\hline 1 & toluene & 10 & 65 & 24 & 25 \\
\hline 2 & toluene & 10 & 85 & 24 & $>98$ \\
\hline 3 & toluene & 10 & 85 & 12 & 70 \\
\hline 4 & toluene & 10 & 100 & 12 & $>98$ \\
\hline 5 & toluene & 5 & 100 & 12 & $>98$ \\
\hline 6 & toluene & 5 & 65 & 70 & $>97$ \\
\hline $7^{c}$ & DMF & 5 & 100 & 12 & $>98$ \\
\hline
\end{tabular}

${ }^{a}$ General reaction conditions: $2.5 \mathrm{~mol} \% \mathrm{Pd}(\mathrm{OAc})_{2}, 5 \mathrm{~mol} \% \mathrm{PPh}_{3}, 8$ equiv. Et ${ }_{3} \mathrm{~N}, 1.1$ equiv. 2a. ${ }^{\mathrm{b}}$ Substrate conversion determined by ${ }^{1} \mathrm{H}-\mathrm{NMR}$ on the reaction mixture obtained after evaporation of the solvent; ${ }^{\mathrm{c}}$ gave a complex mixture of products.

Hence, our next step was to promote the catalytic aminocarbonylation reaction between 4-iodophthalonitrile (1) with a wide range of amines as nucleophiles (2a-2g) to obtain the corresponding carboxamides (Table 2). Several structurally different amines as $N$-nucleophiles were used: three amino acid methyl esters (methyl glycinate (2a), methyl leucinate (2b) and methyl phenylalaninate (2c)), tert-butylamine (2d), N-BOC-ethylenediamine (2e), chalcone (E)-1-(4-aminophenyl)-3-(3,4,5-trimethoxyphenyl)prop-2-en-1-one (2f) [56], and piperazine (2g) (Table 2). Each reaction's progress was followed by TLC of aliquots taken from the reactor via cannula. After complete conversion of $\mathbf{1}$ to the corresponding carboxamides, the reaction mixture was then subjected to work-up and chromatographic purification procedures (See SI), yielding amide substituted phthalonitriles $3 \mathbf{a}-\mathbf{3 g}$, in good isolated yields (54-80\%) at optimized reaction conditions (Table 2) (see also Figures S1-S21, SI).

When aminoesters were used as nucleophiles (2a-2c), $12 \mathrm{~h}$ were necessary for the complete conversion of the substrate, leading to carboxamides $3 \mathbf{a}, 3 \mathbf{b}$ and $3 \mathbf{c}$ in $65 \%, 54 \%$, and $59 \%$ isolated yields, respectively (Table 2, entries 1-3). It is worth mentioning that the yields obtained were higher than the ones reported for the model substrate iodobenzene using similar aminoesters as nucleophiles [57,58]. This may be attributed to the presence of cyano electron-withdrawing groups in 4-iodophthalonitrile, which enables an easier oxidative addition step in the catalytic cycle (A in Figure 1). 
Table 2. Palladium catalyzed aminocarbonylation of 4-iodophthalonitrile using several amines as nucleophiles ${ }^{a}$.

\begin{tabular}{|c|c|c|c|c|c|}
\hline & 1 & $\begin{array}{l}\text { Nucleophile }+ \text { C } \\
\text { 2a-g }\end{array}$ & $\frac{\mathrm{Pd}(\mathrm{OAc})_{2,}}{\text { Toluene, NE }}$ & ${ }_{11}$ & \\
\hline Entry & Nucleophile (NuH) & $\begin{array}{c}\text { Amine/(1) } \\
\text { Ratio (equiv.) }\end{array}$ & Time (h) & Product & Yield (\%) ${ }^{b}$ \\
\hline 1 & & 1.1 & 12 & $3 a$ & 65 \\
\hline 2 & & 1.1 & 12 & & 54 \\
\hline 3 & & 1.1 & 12 & & 59 \\
\hline 4 & & 3.3 & 4 & & 74 \\
\hline 5 & & 1.2 & 3 & & 80 \\
\hline 6 & & 1.2 & 25 & & 70 \\
\hline 7 & & 6 & 7 & & 77 \\
\hline
\end{tabular}

Simpler aliphatic amines such as tert-butylamine (2d) were also used as nucleophiles. In this case, using 3.3 equivalents of $\mathbf{2} \mathbf{d}$, the aminocarbonylation reaction of $\mathbf{1}$ proceeded in the presence of palladium catalyst formed in situ by addition of palladium(II) acetate to triphenylphosphine (in 1:2 molar ratio), using toluene as solvent, under a CO pressure of 5 bar. Complete conversion of 1 was obtained in just $4 \mathrm{~h}$, yielding carboxamide $3 \mathbf{d}$ in $74 \%$ isolated yield (Table 2, entry 4 ).

Moreover, an $N$-mono-protected-ethylenediamine (2e) was also used. We had to prepare the mono-protected amine since, under the same reaction conditions, when unprotected ethylenediamine as nucleophile was used, a complex mixture of $N$-mono and $N, N^{\prime}$-bis-substituted ethylenediamine, along with degradation products was formed, according to ${ }^{1} \mathrm{H}-\mathrm{NMR}$ analysis. To overcome this problem, we then prepared $\mathbf{2 e}$, using tert-butyloxycarbonyl protecting group (BOC group) following a literature procedure [59]. Next, we promoted the aminocarbonylation reaction of $\mathbf{1}$ with nucleophile $\mathrm{N}$-BOC-ethylenediamine (2e), yielding $3 \mathbf{e}$ in $80 \%$ isolated yield after just $3 \mathrm{~h}$ (Table 2, entry 5). Next, the aminocarbonylation of $\mathbf{1}$ with chalcone $\mathbf{2 f}$, which is a potential anti-microbial agent [60], yielded carboxamide $3 \mathrm{f}$ in 70\% isolated yield, under standard reaction conditions, after $25 \mathrm{~h}$ (Table 2, entry 6). Since the chalcone is an aromatic amine, it is expected to be less nucleophilic and, consequently 
a prolonged period of time was necessary for the complete conversion of the substrate $\mathbf{1}$ into the corresponding carboxamide.

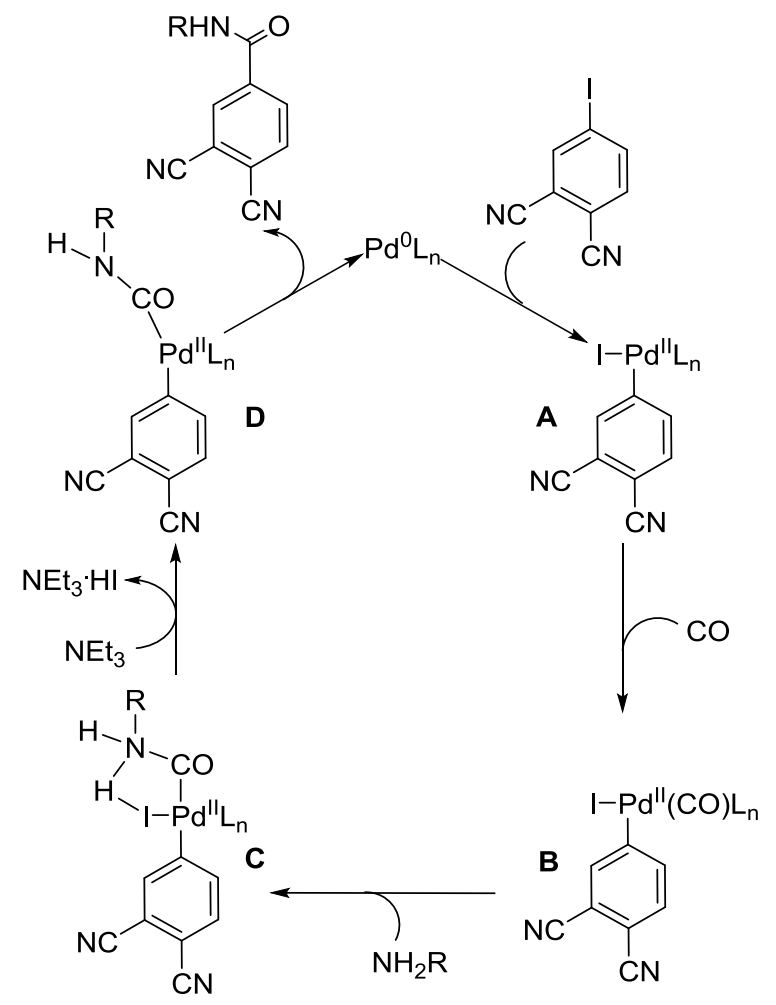

Figure 1. Simplified catalytic cycle describing the formation of 4-amide substituted phthalonitriles. $\mathrm{L}=\mathrm{PPh}_{3}$.

Using similar conditions, we also investigated the use of cyclic diamines in the palladium catalyzed aminocarbonylation reaction for the synthesis of $\mathrm{N}$-mono-substituted diamines. Unprotected diamine piperazine $(\mathbf{2 g})$ is quite useful and interesting because the presence of two amine groups could enable the conjugation with bioactive molecules or functionalization with other relevant chemical groups. In order to attain the desired $\mathrm{N}$-mono-substituted diamine we have selected an excess of 6 equiv. of the diamine $\mathbf{2 g}$. In the presence of palladium catalyst formed in situ by addition of palladium(II) acetate to triphenylphosphine (in 1:2 molar ratio), together with $\mathrm{Et}_{3} \mathrm{~N}$ as base in toluene solvent, under a CO pressure of 5 bar, complete conversion of $\mathbf{1}$ was obtained, after $7 \mathrm{~h}$, yielding carboxamide $\mathbf{3 g}$ after work-up and purification in $77 \%$ isolated yield (Table 2, entry 7 ).

According to previously described [49,51,61-64], a simplified mechanism for the formation of 4 -amide substituted phthalonitrile is proposed in Figure 1. The catalytic cycle begins with the oxidative addition of the in situ formed $\operatorname{Pd}(0) \mathrm{L}_{n}$ active species to the 4-iodophthalonitrile, resulting in an arylpalladium(II) intermediate $\mathbf{A}$, which is able to coordinate to carbon monoxide, leading to intermediate $\mathbf{B}$. Then, this complex undergoes a nucleophilic attack by the desired amine ( $N$-nucleophile), affording $\mathbf{C}$. Through HI elimination with the aid of $\mathrm{Et}_{3} \mathrm{~N}$, intermediate $\mathbf{D}$ is formed, yielding the desired 4-amide substituted phthalonitrile, upon reductive elimination.

All carboxamide substituted phthalonitriles were characterized by ${ }^{1} \mathrm{H},{ }^{13} \mathrm{C}-\mathrm{NMR}$ and mass spectrometry and their structures confirmed. It is worth mentioning that, under the reaction conditions employed ( $100{ }^{\circ} \mathrm{C}$ and $5 \mathrm{bar}$ ), $100 \%$ chemoselectivity toward the mono-carboxamide products was obtained, since no double carbon monoxide insertion product was observed, using these amines as nucleophiles [55,65].

Having established a methodology for the synthesis of several carboxamide-containing phthalonitriles $\mathbf{3 a - 3 g}$, we have then prepared, as selected examples, phthalocyanines $4 \mathbf{a}$, $4 \mathbf{c}$, and $4 \mathbf{d}$, 
starting from the corresponding phthalonitriles 3a, 3c, and 3d (Table 3) (see also Figures S22-S27, SI). We have used an approach where the tetramerization of the phthalonitriles was carried out in pentan-1-ol at $140{ }^{\circ} \mathrm{C}$, in the presence of zinc(II) acetate, for $20 \mathrm{~h}$, with all reactions progress being followed by TLC and UV-VIS spectroscopy. Phthalocyanines $\mathbf{4 a}, \mathbf{4} \mathbf{c}$ and $\mathbf{4 d}$ were obtained, after purification and isolation by column chromatography on silica gel, in 58,65 and $68 \%$ yields, respectively.

We have observed that the purification procedure for phthalocyanines $4 \mathbf{a}$ and $4 \mathbf{c}$ was considerably more demanding than for phthalocyanine $4 \mathrm{~d}$. We have found that, even after repeated recrystallization from methanol/diethyl ether, pentan-1-ol remained coordinated with the waxy phthalocyanine molecules $4 \mathbf{a}$ and $\mathbf{4 c}$, as observable on their corresponding ${ }^{1} \mathrm{H}-\mathrm{NMR}$ spectra. On the other hand, solid phthalocyanine $\mathbf{4 d}$, bearing tert-butyl carboxamide groups, was easily recrystallized from methanol. We assume this occurrence to the nature of the carboxamide substituent, as amino acid derivatives are more prone to establish interactions with alcohol molecules, in our case pentan-1-ol $[66,67]$. This was also corroborated by the elemental analysis of $\mathbf{4 a}$ and $\mathbf{4 c}$, which agreed with the presence of two molecules of pentan-1-ol per molecule of phthalocyanine. All the other typical metallophthalocyanine characteristics in terms of ${ }^{1} \mathrm{H}-\mathrm{NMR}$, mass spectrometry and UV-VIS spectroscopy were met, in agreement with the structures.

Table 3. Synthesis of zinc (II) metallophthalocyanines $4 a, 4 c$, and $4 d$ and their spectral fundamental/excited state properties, studied in THF.

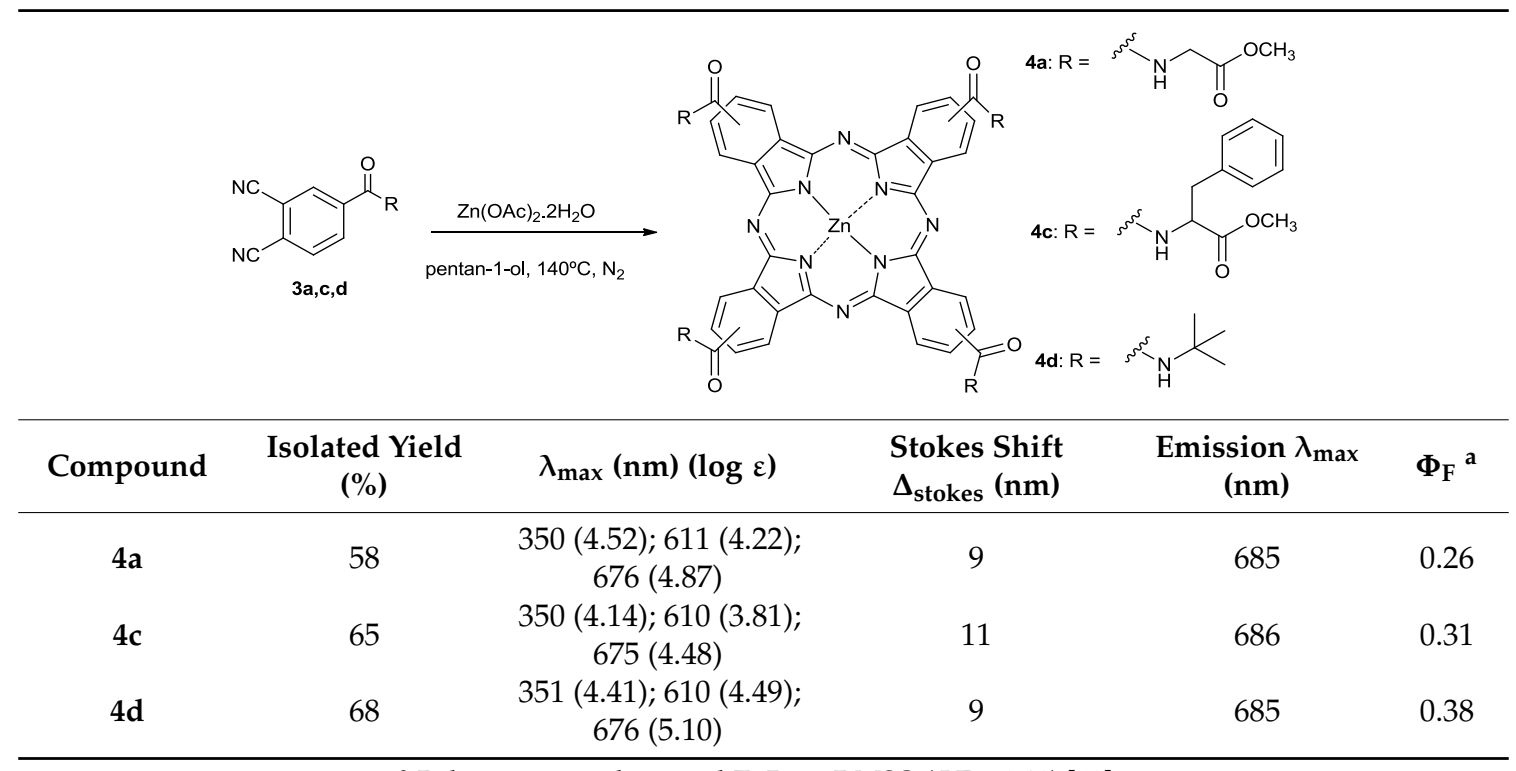

a Relative to unsubstituted ZnPc in DMSO ( $\Phi \mathrm{F}=0.18)[68]$.

Initial photophysical assessment was carried out for the synthesized metallophthalocyanines. Absorption, emission and fluorescence quantum yields for the phthalocyanines $4 \mathbf{a}$, $4 \mathbf{c}$, and $4 \mathbf{d}$ were recorded, using THF as solvent and the results are presented in Table 3.

The electronic absorption spectra of $\mathbf{4 a}, \mathbf{4 c}$, and $\mathbf{4 d}$, whose values of molar absorptivity coefficients $(\varepsilon)$ are in the typical of range for zinc(II) metallophthalocyanines (Table 3 ), showed monomeric behavior evidenced by a single and sharp $Q$ band, typical of non-aggregated metallated phthalocyanine complexes, with a maximum at respectively 676, 675 and $676 \mathrm{~nm}$ in THF, and a Soret band (the B-band) being observed at around $350 \mathrm{~nm}$, as shown in Table 3 and Figure 2a. The B-bands are broad due to the superimposition of the $B_{1}$ and $B_{2}$ bands in the $350 \mathrm{~nm}$ region. Moreover, the absorption spectra, Figure 2a, shows that the introduction of the different substituents at the periphery of the phthalocyanine, does not disturb the UV-VIS spectrum, since the absorption bands maximum are similar. 

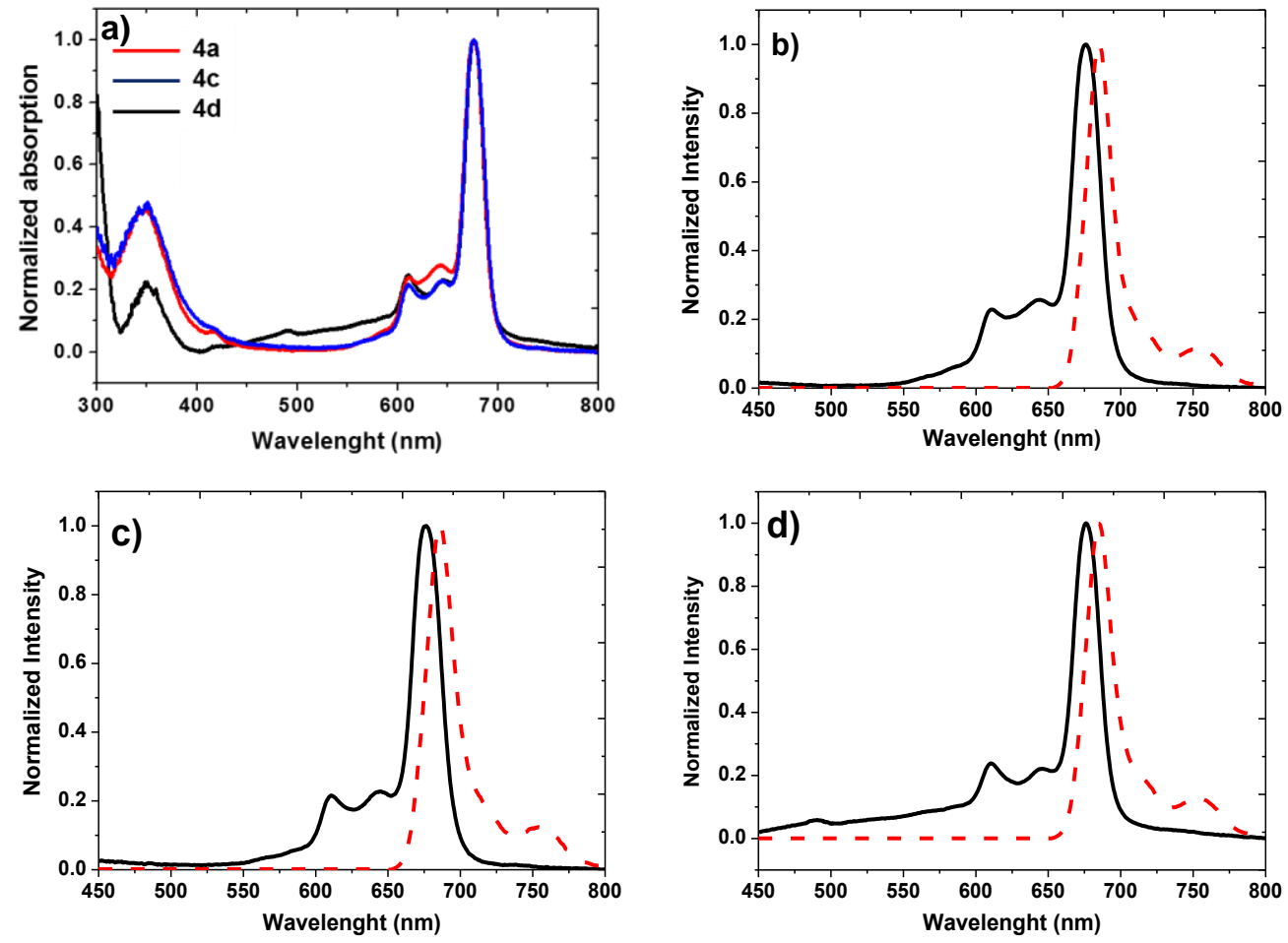

Figure 2. UV-VIS spectra of metallophthalocyanines $\mathbf{4 a}, \mathbf{4 c}$, and $\mathbf{4 d}$ in THF (a); normalized UV-Vis of studied phthalocyanines with absorption (black solid line) and emission spectra (red dashed line) in THF of: $\mathrm{Zn}(\mathrm{II})-\mathbf{4 a}(\mathbf{b}) ; \mathrm{Zn}(\mathrm{II})-\mathbf{4 c}(\mathbf{c}) ; \mathrm{Zn}(\mathrm{II})-\mathbf{4 d}(\mathbf{d})$. Fluorescence quantum yields $\left(\Phi_{\mathrm{F}}\right)$ of the zinc phthalocyanines $\mathbf{4 a}$ and $\mathbf{4} \mathbf{c}-\mathbf{d}$, are presented in Table 3, were determined by the comparative method (Equation (1)) using the unsubstituted Zn phthalocyanine in DMSO as standard $\left(\Phi_{\mathrm{F}}=0.18\right)$ [68], and both the samples and the standard were excited at the same wavelength $(640 \mathrm{~nm})$. The $\Phi_{\mathrm{F}}$ were calculated as $0.26,0.31$ and 0.38 for $4 \mathbf{a}, 4 \mathbf{c}$ and $4 \mathbf{d}$, respectively. The $\Phi_{\mathrm{F}}$ value of zinc phthalocyanine complexes functionalized with the amino acid esters $4 \mathrm{a}$ and $4 \mathrm{c}$ have the same order of magnitude $\left(\Phi_{\mathrm{F}}=0.26-0.31\right)$ and are lower than non-biocompatible zinc phthalocyanine $4 \mathrm{~d}\left(\Phi_{\mathrm{F}}=0.38\right)$.

The steady-state fluorescence emission spectra of the compounds in THF are shown in Figure 2 and the related data were listed with Stokes shifts in Table 3. Upon excitation at $640 \mathrm{~nm}, \mathbf{4 a}, 4 \mathbf{c}$, and $4 \mathrm{~d}$ showed fluorescence emission at 685, 686, and $685 \mathrm{~nm}$, respectively. Again, and as expected, the fluorescence emission spectra of all phthalocyanines were similar, as all zinc metal complexes have maximum emission at the same wavelength $\left(\lambda_{\max }=685-686 \mathrm{~nm}\right)$. It should be noted that the absorption spectra of all phthalocyanines were mirror images of the fluorescent spectra in THF, and that the emission is observed in the region of NIR, a pre-requisite for applications in fluorescence imaging within the important therapeutic window $(\lambda=650-900 \mathrm{~nm})[2,5,69]$. The observed Stokes shifts, were within the region $\approx 9-11 \mathrm{~nm}$ are typical of $\beta$-substituted phthalocyanines, which is a consequence of the rigidity of the macrocyclic ligand [70].

\section{Experimental}

\subsection{Materials and Methods}

Commercially available reagents were purchased from Aldrich (Lisbon, Portugal) and Fluorochem (Derbyshire, UK) and used as received. All solvents were pre-dried according to standard laboratory techniques. UV-VIS absorption spectra were recorded on a Hitachi U-2010 (Hitachi Corporation, Tokyo, Japan) using quartz cells. The molar absorption coefficients were determined using THF as solvent. The fluorescence spectra for the determination of fluorescence quantum yields were acquired on a Spex Fluorolog 3 spectrofluorimeter (Horiba Instruments Incorporated, Edison, NJ, USA). ${ }^{1} \mathrm{H}$ and ${ }^{13} \mathrm{C}-\mathrm{NMR}$ 
spectra were recorded on a Bruker Advance III spectrometer (Bruker, Karlsruhe, Germany) $\left(400.13\right.$ for ${ }^{1} \mathrm{H}$, and $100.61 \mathrm{MHz}$ for ${ }^{13} \mathrm{C}$ ). Chemical shifts for ${ }^{1} \mathrm{H}$ and ${ }^{13} \mathrm{C}$ are expressed in ppm, relatively to an internal pattern of TMS. The MALDI-TOF mass spectra were acquired using a Bruker Daltonics Flex Analysis apparatus (Bruker, Madrid, Spain). High-resolution mass spectrometry analysis was carried out with a Bruker Microtof apparatus (Bruker, Madrid, Spain), equipped with selective ESI detector. Elemental analyses were acquired using a FISONS model EA 1108 (Thermo Scientific, Waltham, MA, USA). Column chromatography was performed with silica gel grade 60, 70-230 mesh. 4-Iodophthalonitrile (1) was prepared according to the literature procedure [53] starting from 4-nitrophthalonitrile. The nucleophiles (E)-1-(4-aminophenyl)-3-(3,4,5-trimethoxyphenyl)prop-2-en-1-one (2f) [56] and $\mathrm{N}$-BOC-ethylenediamine (2e) [59] were prepared as described in the literature.

Fluorescence quantum yields $\left(\Phi_{\mathrm{F}}\right)$ were determined in DMSO using a comparative method with the Equation (1), using unsubstituted zinc(II) phthalocyanine $(\mathrm{ZnPc})$ in DMSO $(\Phi=0.18)[68]$ as standard:

$$
\Phi_{\mathrm{F}}=\Phi_{\mathrm{F}}^{\mathrm{Std}} \frac{\mathrm{F} A_{\mathrm{Std}} \eta^{2}}{\mathrm{~F}_{\mathrm{Std}} \mathrm{A} \eta_{\mathrm{Std}}{ }^{2}}
$$

where $\mathrm{F}$ and $\mathrm{F}_{\mathrm{Std}}$ are the areas under the fluorescence curves of the samples and the standard, respectively; $\mathrm{A}$ and $\mathrm{A}_{\mathrm{Std}}$ are the corresponding absorbances of the samples and standard at the excitation wavelengths, respectively; $\eta^{2}$ and $\eta^{2}$ Std are the refractive indices of solvents used for the sample and standard, respectively. The absorbance of the solutions at the excitation wavelength was around 0.1 .

\subsection{General Procedure for Synthesis of CARBOXAMIDE Substituted Phthalonitriles $\mathbf{3 a - g}$}

In a typical aminocarbonylation reaction, the catalyst precursor $\mathrm{Pd}(\mathrm{OAc})_{2}$, triphenylphosphine $\left(\mathrm{PPh}_{3}\right)$ ligand, substrate 4-iodophthalonitrile and the nucleophile were directly introduced in a high pressure reactor having a magnetic stirrer inside. The reactor was sealed and three vacuum/CO gas cycles were performed. Under vacuum, the reaction solvent was then added (toluene) via cannula, followed by triethylamine as base. The reactor was then pressurized using 5 bar $\mathrm{CO}$ and the reaction mixture maintained at $100{ }^{\circ} \mathrm{C}$ for the required period of time. After this period, the reactor was cooled to room temperature and depressurized. Palladium particles were filtered, the solvent rotary evaporated, and the crude product was then purified according to the corresponding procedure. All new compounds were characterized by means of ${ }^{1} \mathrm{H}-,{ }^{13} \mathrm{C}-\mathrm{NMR}$, and mass spectrometry and presented in ESI.

Methyl 2-(3,4-dicyanobenzamido)acetate (glycine substituted phthalonitrile) (3a). Following the above described procedure, $6.75 \mathrm{mg}(0.030 \mathrm{mmol})$ of $\mathrm{Pd}(\mathrm{OAc})_{2}, 15.74 \mathrm{mg}(0.060 \mathrm{mmol})$ of $\mathrm{PPh}_{3}, 300 \mathrm{mg}$ $(1.18 \mathrm{mmol})$ of 4 -iodophthalonitrile, $163.4 \mathrm{mg}(1.30 \mathrm{mmol})$ glycine methyl ester hydrochloride (2a), and $1.1 \mathrm{~mL} \mathrm{Et}_{3} \mathrm{~N}$ were dissolved in $10 \mathrm{~mL}$ of toluene. The reaction was pressurized and maintained at $100{ }^{\circ} \mathrm{C}$ for $12 \mathrm{~h}$. The residue was dissolved in dichloromethane $(20 \mathrm{~mL})$, washed with brine $(3 \times 20 \mathrm{~mL})$ and water $(3 \times 20 \mathrm{~mL})$. The organic phase was dried with sodium sulfate and the solvent evaporated. The product was purified by recrystallization with ethyl acetate $/ n$-hexane yielding 3a in $65 \%$ yield $(158 \mathrm{mg}) .{ }^{1} \mathrm{H}-\mathrm{NMR}\left(400.13 \mathrm{MHz}, \mathrm{CDCl}_{3}\right) \delta 8.26(\mathrm{~s}, 1 \mathrm{H}), 8.15(\mathrm{~d}, J=8.1 \mathrm{~Hz}, 1 \mathrm{H}), 7.93(\mathrm{~d}, J=8.1 \mathrm{~Hz}$, $1 \mathrm{H}), 6.77(\mathrm{~s}, 1 \mathrm{H}), 4.27(\mathrm{~d}, J=4.9 \mathrm{~Hz}, 2 \mathrm{H}), 3.84(\mathrm{~s}, 9 \mathrm{H}) .{ }^{13} \mathrm{C}-\mathrm{NMR}\left(100.61 \mathrm{MHz}, \mathrm{CDCl}_{3}\right) \delta$ 170.0, 163.7, 138.4, 134.1, 132.4, 131.6, 118.6, 116.9, 114.8, 114.7, 53.0, 42.1. HRMS (ESI-TOF) $m / z$ calcd for $[\mathrm{M}+\mathrm{Na}]^{+}$: $\mathrm{C}_{12} \mathrm{H}_{9} \mathrm{~N}_{3} \mathrm{NaO}_{3}$ 266.0536; found 266.0532.

(S)-Methyl 2-(3,4-dicyanobenzamido)-4-methylpentanoate (leucine substituted phthalonitrile) (3b). Following the above described procedure, $6.75 \mathrm{mg}(0.030 \mathrm{mmol})$ of $\mathrm{Pd}(\mathrm{OAc})_{2}, 15.74 \mathrm{mg}$ ( $0.06 \mathrm{mmol})$ of $\mathrm{PPh}_{3}, 300 \mathrm{mg}(1.18 \mathrm{mmol})$ of 4 -iodophthalonitrile, $236.6 \mathrm{mg}$ (1.30 mmol) leucine methyl ester hydrochloride $(\mathbf{2 b})$ and $1.1 \mathrm{~mL} \mathrm{Et}_{3} \mathrm{~N}$ were dissolved in $10 \mathrm{~mL}$ toluene. The reaction was pressurized and maintained at $100{ }^{\circ} \mathrm{C}$ for $12 \mathrm{~h}$. The residue was dissolved in dichloromethane $(20 \mathrm{~mL})$, washed with brine $(3 \times 20 \mathrm{~mL})$ and water $(3 \times 20 \mathrm{~mL})$.The organic phase was dried with sodium sulfate and the solvent evaporated. The product $(\mathbf{3 b})$ was purified by column chromatography on 
silica gel (stationary phase) first using chloroform and then a mixture of chloroform/ethyl acetate (20/1) and obtained in 54\% yield (120 mg), after being washed with $n$-hexane. ${ }^{1} \mathrm{H}-\mathrm{NMR}(400.13 \mathrm{MHz}$, $\left.\mathrm{CDCl}_{3}\right) \delta 8.24(\mathrm{~d}, J=8.1 \mathrm{~Hz}, 1 \mathrm{H}), 8.14(\mathrm{dd}, J=1.7 \mathrm{~Hz}, J=8.1 \mathrm{~Hz}, 1 \mathrm{H}), 7.91(\mathrm{~d}, J=8.1 \mathrm{~Hz}, 1 \mathrm{H}), 6.77(\mathrm{br}$ $\mathrm{s}, 1 \mathrm{H}), 4.86-4.80(\mathrm{~m}, 1 \mathrm{H}), 3.79(\mathrm{~s}, 3 \mathrm{H}), 1.80-1.66(2 \mathrm{~m}, 3 \mathrm{H}), 1.00-0.97(\mathrm{~m}, 6 \mathrm{H}) .{ }^{13} \mathrm{C}-\mathrm{NMR}(100.61 \mathrm{MHz}$, $\left.\mathrm{CDCl}_{3}\right) \delta 173.4,163.5,138.6,134.1,132.4,131.9,118.3,116.6,114.9,52.9,51.8,41.6,25.1,22.9,22.0$. HRMS (ESI-TOF) $m / z$ calcd for $[\mathrm{M}+\mathrm{Na}]^{+}: \mathrm{C}_{16} \mathrm{H}_{17} \mathrm{~N}_{3} \mathrm{NaO}_{3}$ 322.1162; found 322.1153.

(S)-Methyl 2-(3,4-dicyanobenzamido)-3-phenylpropanoate (phenyl alanine substituted phthalonitrile) (3c). Following the above described procedure, $6.75 \mathrm{mg}(0.030 \mathrm{mmol})$ of $\mathrm{Pd}(\mathrm{OAc})_{2}$, $15.74 \mathrm{mg}(0.06 \mathrm{mmol})$ of $\mathrm{PPh}_{3}, 300 \mathrm{mg}(1.18 \mathrm{mmol})$ of 4-iodophthalonitrile, $280.4 \mathrm{mg}(1.30 \mathrm{mmol})$ phenyl alanine methyl ester hydrochloride $(2 \mathrm{c})$ and $1.1 \mathrm{~mL} \mathrm{Et}_{3} \mathrm{~N}$ were dissolved in $10 \mathrm{~mL}$ toluene. The reaction was pressurized and maintained at $100{ }^{\circ} \mathrm{C}$ for $12 \mathrm{~h}$. The residue was dissolved in dichloromethane $(20 \mathrm{~mL})$, washed with brine $(3 \times 20 \mathrm{~mL})$ and water $(3 \times 20 \mathrm{~mL})$. The organic phase was dried with sodium sulfate and the solvent evaporated. The product (3c) was purified by column chromatography on silica gel (stationary phase) first using chloroform and then a mixture of chloroform/ethyl acetate (10/1) and obtained in 59.0\% yield (192 mg), after being washed with $n$-hexane. ${ }^{1} \mathrm{H}-\mathrm{NMR}\left(400.13 \mathrm{MHz}, \mathrm{CDCl}_{3}\right) \delta 8.12(\mathrm{~d}, J=1.7 \mathrm{~Hz}, 1 \mathrm{H}), 8.00(\mathrm{dd}, J=8.1,1.7 \mathrm{~Hz}, 1 \mathrm{H}), 7.88$ $(\mathrm{d}, J=8.1 \mathrm{~Hz}, 1 \mathrm{H}), 7.30-7.29(\mathrm{~m}, 3 \mathrm{H}), 7.10-7.08(\mathrm{~m}, 2 \mathrm{H}), 6.64(\mathrm{br} \mathrm{s}, 1 \mathrm{H}), 5.09-5.04(\mathrm{~m}, 1 \mathrm{H}), 3.82(\mathrm{~s}$, 3H), 3.34-3.21 (m, 2H). ${ }^{13} \mathrm{C}-\mathrm{NMR}\left(100.61 \mathrm{MHz}, \mathrm{CDCl}_{3}\right) \delta 171.7,163.3,138.6,135.4,134.1,132.4,131.6$, $129.3,128.9,127.6,118.4,116.6,114.8,114.8,54.0,52.9,37.7$. HRMS (ESI-TOF) $m / z$ calcd for $[\mathrm{M}+\mathrm{Na}]^{+}$: $\mathrm{C}_{19} \mathrm{H}_{15} \mathrm{~N}_{3} \mathrm{NaO}_{3}$ 356.1003; found 356.1006 .

N-Tert-butyl-3,4-dicyanobenzamide (3d). Following the above described procedure, $4.4 \mathrm{mg}$ $(0.020 \mathrm{mmol})$ of $\mathrm{Pd}(\mathrm{OAc})_{2}, 10.5 \mathrm{mg}(0.040 \mathrm{mmol})$ of $\mathrm{PPh}_{3}, 200 \mathrm{mg}(0.79 \mathrm{mmol})$ of 4-iodophthalonitrile, $0.28 \mathrm{~mL}(2.6 \mathrm{mmol})$ of tert-butyl amine (2d) and $0.8 \mathrm{~mL} \mathrm{Et}_{3} \mathrm{~N}$ were dissolved in $6 \mathrm{~mL}$ of toluene. The reaction was pressurized and maintained at $100{ }^{\circ} \mathrm{C}$ for $4 \mathrm{~h}$. The residue was dissolved in dichloromethane $(20 \mathrm{~mL})$, washed with brine $(3 \times 20 \mathrm{~mL})$ and water $(3 \times 20 \mathrm{~mL})$. The organic phase was dried with sodium sulfate and the solvent evaporated. The product (3d) was purified by column chromatography on silica gel (stationary phase) using a mixture of dichloromethane/ethyl acetate (20/1) and obtained in 74\% yield (132.9 mg). ${ }^{1} \mathrm{H}-\mathrm{NMR}\left(400.13 \mathrm{MHz}, \mathrm{CDCl}_{3}\right) \delta 8.14(\mathrm{bs}, 1 \mathrm{H})$, $8.06(\mathrm{~d}, J=8.1 \mathrm{~Hz}, 1 \mathrm{H}), 7.88(\mathrm{~d}, J=8.1 \mathrm{~Hz}, 1 \mathrm{H}), 5.94(\mathrm{br} \mathrm{s}, 1 \mathrm{H}), 1.49(\mathrm{~s}, 9 \mathrm{H}) .{ }^{13} \mathrm{C}-\mathrm{NMR}(100.61 \mathrm{MHz}$, $\left.\mathrm{CDCl}_{3}\right) \delta 163.1,140.6,134.0,132.1,131.6,117.8,116.4,115.0,53.0,28.8$. HRMS (EI) $m / z$ calcd for $[\mathrm{M}]^{+}$: $\mathrm{C}_{13} \mathrm{H}_{13} \mathrm{~N}_{3} \mathrm{O}$ 227.1059; found: 227.1060.

N-BOC-Ethylenediamine-3,4-dicyanobenzamide (3e). Following the above described procedure, $4.4 \mathrm{mg}(0.020 \mathrm{mmol})$ of $\mathrm{Pd}(\mathrm{OAc})_{2}, 10.5 \mathrm{mg}(0.040 \mathrm{mmol})$ of $\mathrm{PPh}_{3}, 200 \mathrm{mg}(0.79 \mathrm{mmol})$ of 4-iodophthalonitrile, $151 \mathrm{mg}(0.94 \mathrm{mmol})$ of $\mathrm{N}$-BOC-ethylenediamine (2e) and $0.8 \mathrm{~mL} \mathrm{Et}_{3} \mathrm{~N}$ were dissolved in $6 \mathrm{~mL}$ toluene. The reaction was pressurized and maintained at $100^{\circ} \mathrm{C}$ for $3 \mathrm{~h}$. The product (3e) precipitated in the middle of the reaction and then was washed with $n$-hexane and obtained in $80 \%$ yield (198.5 mg). ${ }^{1} \mathrm{H}-\mathrm{NMR}\left(400.13 \mathrm{MHz}, \mathrm{CDCl}_{3}\right) \delta 8.31(\mathrm{sl}, 1 \mathrm{H}), 8.21(\mathrm{dd}, J=8.1,1.1 \mathrm{~Hz}, 1 \mathrm{H}), 8.17$ (br s, 1H), $7.89(\mathrm{~d}, J=8.1 \mathrm{~Hz}, 1 \mathrm{H}), 5.18(\mathrm{br} \mathrm{s}, 1 \mathrm{H}), 3.56-3.53(\mathrm{~m}, 2 \mathrm{H}), 3.43-3.41(\mathrm{~m}, 2 \mathrm{H}), 1.43(\mathrm{~s}, 9 \mathrm{H})$. ${ }^{13} \mathrm{C}-\mathrm{NMR}\left(100.61 \mathrm{MHz}, \mathrm{CDCl}_{3}\right) \delta 163.6,158.7,138.9,133.9,132.4,131.7,117.9,116.4,115.0,114.9,80.9$, 43.6, 39.7, 28.4. HRMS (ESI-TOF) $m / z$ calcd for $[\mathrm{M}+\mathrm{H}]^{+}: \mathrm{C}_{16} \mathrm{H}_{18} \mathrm{~N}_{4} \mathrm{NaO}_{3}$ 337.1271; found 337.1271.

(E)-3,4-Dicyano-N-(4-(3-(3,4,5-trimethoxyphenyl)acryloyl)phenyl)benzamide (3f). Following the above described procedure, $4.4 \mathrm{mg}(0.020 \mathrm{mmol})$ of $\mathrm{Pd}(\mathrm{OAc})_{2}, 10.5 \mathrm{mg}(0.040 \mathrm{mmol})$ of $\mathrm{PPh}_{3}, 200 \mathrm{mg}(0.79 \mathrm{mmol})$ of 4-iodophthalonitrile, $296 \mathrm{mg}$ (0.94 mmol) of (E)-1-(4-aminophenyl)-3(3,4,5-trimethoxyphenyl)prop-2-en-1-one (2f), and $0.8 \mathrm{~mL} \mathrm{Et}_{3} \mathrm{~N}$ were dissolved in $6 \mathrm{~mL}$ toluene. The reaction was pressurized and maintained at $100{ }^{\circ} \mathrm{C}$ for $25 \mathrm{~h}$. The product (3f) precipitated in the middle of reaction and was washed with methanol and cyclohexane and obtained in $70 \%$ yield $(256 \mathrm{mg})$. ${ }^{1} \mathrm{H}-\mathrm{NMR}\left(400.13 \mathrm{MHz}\right.$, acetone- $\left.d_{6}\right) \delta 10.23(\mathrm{~s}, 1 \mathrm{H}), 8.64(\mathrm{~d}, J=1.5 \mathrm{~Hz}, 1 \mathrm{H}), 8.51(\mathrm{dd}, J=8.2,1.6 \mathrm{~Hz}, 1 \mathrm{H})$, $8.26(\mathrm{~d}, J=8.2 \mathrm{~Hz}, 1 \mathrm{H}), 8.18(\mathrm{~d}, J=8.7 \mathrm{~Hz}, 2 \mathrm{H}), 8.01(\mathrm{~d}, J=8.7 \mathrm{~Hz}, 2 \mathrm{H}), 7.84(\mathrm{~d}, J=15.5 \mathrm{~Hz}, 1 \mathrm{H}), 7.73(\mathrm{~d}$, $J=15.5 \mathrm{~Hz}, 1 \mathrm{H}), 7.19(\mathrm{~s}, 2 \mathrm{H}), 3.91(\mathrm{~s}, 6 \mathrm{H}), 3.79(\mathrm{~s}, 3 \mathrm{H}) .{ }^{13} \mathrm{C}-\mathrm{NMR}\left(100.61 \mathrm{MHz}\right.$, acetone- $\left.d_{6}\right) \delta 188.7,163.9$, 
$154.9,145.3,143.8,141.8,140.6,135.4,133.9,133.8,131.8,130.7,122.1,120.8,120.7,118.9,117.0,116.3$, 107.4, 60.9, 56.8. HRMS (ESI-TOF) $m / z$ calcd for $[\mathrm{M}]^{+}: \mathrm{C}_{27} \mathrm{H}_{21} \mathrm{~N}_{3} \mathrm{O}_{5}$ 468.1554; found 468.1555.

N-Piperazine-3,4-dicyanobenzamide (3g). Following the above described procedure, $4.4 \mathrm{mg}$ $(0.020 \mathrm{mmol})$ of $\mathrm{Pd}(\mathrm{OAc})_{2}, 10.5 \mathrm{mg}(0.040 \mathrm{mmol})$ of $\mathrm{PPh}_{3}, 200 \mathrm{mg}(0.79 \mathrm{mmol})$ of 4-iodophthalonitrile, $407 \mathrm{mg}$ ( $4.72 \mathrm{mmol}$ ) piperazine $(2 \mathrm{~g})$, and $0.8 \mathrm{~mL} \mathrm{Et}_{3} \mathrm{~N}$ were dissolved in $6 \mathrm{~mL}$ toluene. The reaction was pressurized and maintained at $100{ }^{\circ} \mathrm{C}$ for $7 \mathrm{~h}$. The product (3g) was purified by column chromatography on silica gel (stationary phase) using ethanol as eluent and obtained in $77 \%$ yield $(146 \mathrm{mg}) .{ }^{1} \mathrm{H}$-NMR $\left(400.13 \mathrm{MHz}, \mathrm{CDCl}_{3}\right) \delta 7.87(\mathrm{~d}, J=8.0 \mathrm{~Hz}, 1 \mathrm{H}), 7.83(\mathrm{~d}, J=1.3 \mathrm{~Hz}, 1 \mathrm{H}), 7.75(\mathrm{dd}, J=8.0,1.3 \mathrm{~Hz}, 1 \mathrm{H})$, $3.75(\mathrm{~s}, 2 \mathrm{H}), 3.32(\mathrm{~s}, 2 \mathrm{H}), 2.90(\mathrm{~d}, J=49.8 \mathrm{~Hz}, 4 \mathrm{H}) .{ }^{13} \mathrm{C}-\mathrm{NMR}\left(100.61 \mathrm{MHz}, \mathrm{CDCl}_{3}\right) \delta 166.1,141.1,134.0$, $132.2,131.7,116.8,116.7,114.9,114.8,49.01,46.6,45.9,43.6$. HRMS (ESI-TOF) $m / z$ calcd for $[\mathrm{M}+\mathrm{H}]^{+}$: $\mathrm{C}_{13} \mathrm{H}_{13} \mathrm{~N}_{4} \mathrm{O} 241.1084$; found 241.1081.

\subsection{General Procedure for Synthesis of Carboxamide Substituted Phthalocyanines}

In a typical experiment, the desired phthalonitrile and $\mathrm{Zn}(\mathrm{OAc})_{2} \cdot 2 \mathrm{H}_{2} \mathrm{O}$ were dissolved in high boiling solvent pentan-1-ol and the mixture heated to reflux temperature for the required time for total consumption of the substrate (checked by TLC) under nitrogen atmosphere. After distilling off most of the solvent, the mixture was cooled to room temperature, and $n$-hexane was added to precipitate the crude compound. The solid was filtered, washed with water and purified according to the corresponding procedure. All new compounds were characterized by means of ${ }^{1} \mathrm{H}-\mathrm{NMR}, \mathrm{UV}-\mathrm{VIS}$, fluorescence and mass spectrometry and presented in ESI.

2(3)-Tetra-(keto-N-glycinyl) phthalocyaninato zinc(II) (4a). Following the procedure described above, $100 \mathrm{mg}$ of phthalonitrile $3 \mathrm{a}(0.41 \mathrm{mmol})$ and $29.7 \mathrm{mg} \mathrm{Zn}(\mathrm{OAc})_{2} \cdot 2 \mathrm{H}_{2} \mathrm{O}(0.14 \mathrm{mmol})$ were dissolved in $1 \mathrm{~mL}$ of pentan-1-ol. The mixture was heated to $140{ }^{\circ} \mathrm{C}$ and stirred for $20 \mathrm{~h}$. After workup procedure, the zinc(II) phthalocyanine complex 4a was purified by column chromatography on silica gel first using dichloromethane/ethyl acetate $(1 / 1)$ and then a mixture of dichloromethane/ethanol (20/1) as eluent to obtain $62 \mathrm{mg}$ of $4 \mathbf{a}$ ( $58 \%$ yield), as a waxy dark blue solid. UV-VIS (THF) $\lambda_{\max }$ $(\log \varepsilon) 350$ (4.52), $611(4.22), 676(4.87) .{ }^{1} \mathrm{H}-\mathrm{NMR}\left(400.13 \mathrm{MHz}\right.$, acetone- $\left.d_{6}, 30{ }^{\circ} \mathrm{C}\right) \delta 8.46(\mathrm{br} \mathrm{s}, 4 \mathrm{H})$, $8.34(\mathrm{~d}, J=7.7 \mathrm{~Hz}, 4 \mathrm{H}), 8.29(\mathrm{~s}, 4 \mathrm{H}), 7.94(\mathrm{~d}, J=7.7 \mathrm{~Hz}, 4 \mathrm{H}), 4.04-3.94(\mathrm{~m}, 8 \mathrm{H}), 2.76(\mathrm{~s}, 12 \mathrm{H}) . \mathrm{MS}$ (MALDI-TOF-INFUSION) $\mathrm{m} / \mathrm{z}$ calcd for $\left[\mathrm{M}+\mathrm{Li}^{+}: \mathrm{C}_{48} \mathrm{H}_{36} \mathrm{~N}_{12} \mathrm{O}_{12} \mathrm{LiZn}\right.$ 1043.2023; found 1043.2050. EA calcd for $\mathrm{C}_{48} \mathrm{H}_{36} \mathrm{~N}_{12} \mathrm{O}_{12} \mathrm{Zn} \cdot 2 \mathrm{C}_{5} \mathrm{H}_{12} \mathrm{O} \cdot 2 \mathrm{H}_{2} \mathrm{O}$ C, 55.70; H, 5.16; N, 13.44; found $\mathrm{C}, 55.55 ; \mathrm{H}, 5.35 ; \mathrm{N}, 13.50$.

$(S, S, S, S)-2(3)$-Tetra-(keto- $N$-phenyl alaninyl) phthalocyaninato zinc(II) (4c). Following the procedure described above, $45 \mathrm{mg}$ of phthalonitrile $3 \mathrm{c}(0.14 \mathrm{mmol})$ and $11 \mathrm{mg} \mathrm{Zn}(\mathrm{OAc})_{2} \cdot 2 \mathrm{H}_{2} \mathrm{O}$ $(0.05 \mathrm{mmol})$ were dissolved in $0.5 \mathrm{~mL}$ of pentan-1-ol. The mixture was heated to $140{ }^{\circ} \mathrm{C}$ and stirred for $20 \mathrm{~h}$. After workup procedure, the zinc(II) phthalocyanine complex $4 \mathrm{c}$ was purified by column chromatography on silica gel first using dichloromethane/ethyl acetate (5/1) and then a mixture of dichloromethane/ethanol (20/1) as eluent to obtain $32 \mathrm{mg}$ of $4 \mathrm{c}(65 \%$ yield), as a waxy dark blue solid. UV-VIS (THF) $\lambda_{\max }(\log \varepsilon) 350(4.14), 610(3.81), 675(4.48) .{ }^{1} \mathrm{H}-\mathrm{NMR}\left(400.13 \mathrm{MHz}\right.$, acetone- $\left.d_{6}\right) \delta 8.34$ (br s, $4 \mathrm{H}), 8.24(\mathrm{~d}, J=7.8 \mathrm{~Hz} 4 \mathrm{H}), 8.20(\mathrm{~s}, 4 \mathrm{H}), 7.89(\mathrm{~d}, J=7.7 \mathrm{~Hz}, 4 \mathrm{H}), 7.27(2 \mathrm{~m}, 20 \mathrm{H}), 4.93(\mathrm{~m}, 4 \mathrm{H}), 3.31$ $(\mathrm{m}, 4 \mathrm{H}), 3.19(\mathrm{~m}, 4 \mathrm{H}), 2.86(\mathrm{~s}, 12 \mathrm{H})$. MS (ESI-TOF-INFUSION) $\mathrm{m} / z$ calcd for $[\mathrm{M}]^{+}: \mathrm{C}_{76} \mathrm{H}_{60} \mathrm{~N}_{12} \mathrm{O}_{12} \mathrm{Zn}$ 1396.3745; found 1396.3754. EA calcd for $\mathrm{C}_{76} \mathrm{H}_{60} \mathrm{~N}_{12} \mathrm{O}_{12} \mathrm{Zn} \cdot 2 \mathrm{C}_{5} \mathrm{H}_{12} \mathrm{O} \cdot \mathrm{H}_{2} \mathrm{O} \mathrm{C}, 64.84 ; \mathrm{H}, 5.44 ; \mathrm{N}, 10.55$; found $\mathrm{C}, 64.59 ; \mathrm{H}, 5.75 ; \mathrm{N}, 10.83$.

2(3)-Tetra-(tert-butyl-carboxamidyl) phthalocyaninato zinc(II) (4d). Following the procedure described above, $100 \mathrm{mg}$ of phthalonitrile $3 \mathbf{d}(0.44 \mathrm{mmol})$ and $32.9 \mathrm{mg} \mathrm{Zn}(\mathrm{OAc})_{2} \cdot 2 \mathrm{H}_{2} \mathrm{O}(0.15 \mathrm{mmol})$ were dissolved in $0.5 \mathrm{~mL}$ of pentan-1-ol. The mixture was heated to $140{ }^{\circ} \mathrm{C}$ and stirred for $20 \mathrm{~h}$. After workup procedure, the zinc(II) phthalocyanine complex (4d) was purified by column chromatography on silica gel using a mixture dichloromethane/methanol (20/1) as eluent to obtain $74 \mathrm{mg}$ of (4d) $(68 \%$ yield) as a dark blue solid, after recrystallization from methanol. UV-VIS (THF) $\lambda_{\max }(\log \varepsilon) 351$ (4.41), 610 (4.49), 676 (5.10). ${ }^{1} \mathrm{H}-\mathrm{NMR}\left(400.13 \mathrm{MHz}\right.$, acetone- $\left.d_{6}\right) \delta 8.26-8.20$ (br s, 8H), 7.88-7.86 (br s, 4H), $7.58(\mathrm{~s}, 4 \mathrm{H}), 1.48(\mathrm{sl}, 36 \mathrm{H})$. MS (MALDI-TOF) $m / z$ calcd for $[\mathrm{M}]^{+}: \mathrm{C}_{52} \mathrm{H}_{52} \mathrm{~N}_{12} \mathrm{O}_{4} \mathrm{Zn}$ 972.3; found 972.3; 
$[\mathrm{M}+\mathrm{Na}]^{+}, m / z$ : 995.3. EA calcd for $\mathrm{C}_{52} \mathrm{H}_{52} \mathrm{~N}_{12} \mathrm{O}_{4} \mathrm{Zn} \cdot 2 \mathrm{H}_{2} \mathrm{O}$ C, 61.81; $\mathrm{H}, 5.59 ; \mathrm{N}, 16.63$; found $\mathrm{C}, 62.06$; $\mathrm{H}, 5.50 ; \mathrm{N}, 16.43$.

\section{Conclusions}

In conclusion, we have established a straightforward methodology to prepare carboxamide substituted phthalonitriles, using the well-known palladium-catalyzed aminocarbonylation of aryl halides in the presence of carbon monoxide (CO) to our advantage. In virtue of this direct modification of phthalonitriles, a more accessible preparation of biocompatible phthalocyanines is, hence, achieved. Current efforts are being devoted to extending the methodology to other phthalonitriles and phthalocyanines thereof. Initial assessment of the photophysical properties led us to conclude that this type of phthalocyanines may be usable in medicinal applications, namely optical fluorescence imaging, given the high fluorescence quantum yields $\left(\Phi_{\mathrm{F}}=0.31\right.$ for biocompatible amino acid ester substituted phthalocyanine $\mathbf{4 c}$ ) and acceptable Stokes shifts.

Supplementary Materials: The following are available online at http:/ / www.mdpi.com/2073-4344/8/10/480/s1, 1. Experimental procedures for the synthesis of phthalonitriles $3 \mathbf{a}-\mathrm{g}$ and copies of $1 \mathrm{H}, 13 \mathrm{C}$ NMR and Mass Spectra, 2. Experimental procedures for the synthesis of phthalocyanines and copies of $1 \mathrm{H}$ NMR and Mass Spectra.

Author Contributions: Conceptualization: M.J.F.C. and M.M.P.; investigation: V.A.T., M.J.F.C., C.S.V. and R.T.A.; methodology: M.M.P.; supervision: M.J.F.C.; validation: V.A.T., C.S.V. and R.T.A.; writing—original draft: V.A.T., M.J.F.C. and M.M.P.; writing—review and editing: M.J.F.C. and M.M.P.

Funding: This research was funded by FCT-Portugal (Portuguese Foundation for Science and Technology) and FEDER (ERDF)-European Regional Development Fund through the COMPETE Programme (Operational Programme for Competitiveness) with grants PEst-OE/QUI/UI0313/2014, to PT2020 POCI-01-0145-FEDER-027996, PTDC/QEQ-MED/3521/2014 and PTDC/QUI-OUT/27996/2017. M.J.F.C. post-doctoral grant SFRH/BPD/99698/2014 funded by FCT-Portugal. C.S.V., V.A.T. and R.T.A. PhD grants (PD/BD/128317/2017, PD/BD/128318/2017 and PD/BI/135341/2017, respectively) funded by FCT-Portugal. APC waived by MDPI.

Conflicts of Interest: There are no conflicts to declare.

\section{References and Notes}

1. Lovell, J.F.; Liu, T.W.B.; Chen, J.; Zheng, G. Activatable Photosensitizers for Imaging and Therapy. Chem. Rev. 2010, 110, 2839-2857. [CrossRef] [PubMed]

2. Josefsen, L.B.; Boyle, R.W. Unique Diagnostic and Therapeutic Roles of Porphyrins and Phthalocyanines in Photodynamic Therapy, Imaging and Theranostics. Theranostics 2012, 2, 916-966. [CrossRef] [PubMed]

3. Jiblaoui, A.; Leroy-Lhez, S.; Ouk, T.S.; Grenier, K.; Sol, V. Novel polycarboxylate porphyrins: Synthesis, characterization, photophysical properties and preliminary antimicrobial study against Gram-positive bacteria. Bioorg. Med. Chem. Lett. 2015, 25, 355-362. [CrossRef] [PubMed]

4. Calvete, M.J.F.; Pinto, S.M.A.; Pereira, M.M.; Geraldes, C.F.G.C. Metal coordinated pyrrole-based macrocycles as contrast agents for magnetic resonance imaging technologies: Synthesis and applications. Coordin. Chem. Rev. 2017, 333, 82-107. [CrossRef]

5. Calvete, M.J.F.; Simoes, A.V.C.; Henriques, C.A.; Pinto, S.M.A.; Pereira, M.M. Tetrapyrrolic Macrocycles: Potentialities in Medical Imaging Technologies. Curr. Org. Synth. 2014, 11, 127-140. [CrossRef]

6. Tekdas, D.A.; Garifullin, R.; Senturk, B.; Zorlu, Y.; Gundogdu, U.; Atalar, E.; Tekinay, A.B.; Chernonosov, A.A.; Yerli, Y.; Dumoulin, F.; et al. Design of a Gd-DOTA-Phthalocyanine Conjugate Combining MRI Contrast Imaging and Photosensitization Properties as a Potential Molecular Theranostic. Photochem. Photobiol. 2014, 90, 1376-1386. [CrossRef] [PubMed]

7. Sorokin, A.B. Phthalocyanine Metal Complexes in Catalysis. Chem. Rev. 2013, 113, 8152-8191. [CrossRef] [PubMed]

8. Calvete, M.J.F.; Silva, M.; Pereira, M.M.; Burrows, H.D. Inorganic helping organic: Recent advances in catalytic heterogeneous oxidations by immobilised tetrapyrrolic macrocycles in micro and mesoporous supports. RSC Adv. 2013, 3, 22774-22789. [CrossRef]

9. Li, L.L.; Diau, E.W.G. Porphyrin-sensitized solar cells. Chem. Soc. Rev. 2013, 42, 291-304. [CrossRef] [PubMed] 
10. Urbani, M.; Gratzel, M.; Nazeeruddin, M.K.; Torres, T. Meso-Substituted Porphyrins for Dye-Sensitized Solar Cells. Chem. Rev. 2014, 114, 12330-12396. [CrossRef] [PubMed]

11. Bayda, M.; Dumoulin, F.; Hug, G.L.; Koput, J.; Gorniaka, R.; Wojcik, A. Fluorescent H-aggregates of an asymmetrically substituted mono-amino Zn(II) phthalocyanine. Dalton Trans. 2017, 46, 1914-1926. [CrossRef] [PubMed]

12. Jiblaoui, A.; Brevier, J.; Ducourthial, G.; Gonzalez-Nunez, H.; Baudequin, C.; Sol, V.; Leroy-Lhez, S. Modulation of intermolecular interactions in new pyrimidine-porphyrin system as two-photon absorbing photosensitizers. Tetrahedron 2015, 71, 2428-2434. [CrossRef]

13. Dini, D.; Calvete, M.J.F.; Hanack, M. Nonlinear Optical Materials for the Smart Filtering of Optical Radiation. Chem. Rev. 2016, 116, 13043-13233. [CrossRef] [PubMed]

14. Calvete, M.J.F.; Dini, D. Conjugated macrocyclic materials with photoactivated optical absorption for the control of energy transmission delivered by pulsed radiations. J. Photochem. Photobiol. C Photochem. Rev. 2018, 35, 56-73. [CrossRef]

15. Dumoulin, F.; Durmus, M.; Ahsen, V.; Nyokong, T. Synthetic pathways to water-soluble phthalocyanines and close analogs. Coord. Chem. Rev. 2010, 254, 2792-2847. [CrossRef]

16. Pinto, S.M.A.; Tome, V.A.; Calvete, M.J.F.; Pereira, M.M.; Burrows, H.D.; Cardoso, A.M.S.; Pallier, A.; Castro, M.M.C.A.; Toth, E.; Geraldes, C.F.G.C. The quest for biocompatible phthalocyanines for molecular imaging: Photophysics, relaxometry and cytotoxicity studies. J. Inorg. Biochem. 2016, 154, 50-59. [CrossRef] [PubMed]

17. Hanack, M.; Crucius, G.; Calvete, M.J.F.; Ziegler, T. Glycosylated Metal Phthalocyanines. Curr. Org. Synth. 2014, 11, 59-66. [CrossRef]

18. Lobo, A.C.S.; Silva, A.D.; Tome, V.A.; Pinto, S.M.A.; Silva, E.F.F.; Calvete, M.J.F.; Gomes, C.M.F.; Pereira, M.M.; Arnaut, L.G. Phthalocyanine Labels for Near-Infrared Fluorescence Imaging of Solid Tumors. J. Med. Chem. 2016, 59, 4688-4696. [CrossRef] [PubMed]

19. Simoes, A.V.C.; Adamowicz, A.; Dabrowski, J.M.; Calvete, M.J.F.; Abreu, A.R.; Stochel, G.; Arnaut, L.G.; Pereira, M.M. Amphiphilic meso(sulfonate ester fluoroaryl)porphyrins: Refining the substituents of porphyrin derivatives for phototherapy and diagnostics. Tetrahedron 2012, 68, 8767-8772. [CrossRef]

20. Roffey, S.J.; Obach, R.S.; Gedge, J.I.; Smith, D.A. What is the objective of the mass balance study? A retrospective analysis of data in animal and human excretion studies employing radiolabeled drugs. Drug Metab. Rev. 2007, 39, 17-43. [CrossRef] [PubMed]

21. Ball, D.J.; Mayhew, S.; Wood, S.R.; Griffiths, J.; Vernon, D.I.; Brown, S.B. A comparative study of the cellular uptake and photodynamic efficacy of three novel zinc phthalocyanines of differing charge. Photochem. Photobiol. 1999, 69, 390-396. [CrossRef]

22. Anderson, N.; Borlak, J. Drug-induced phospholipidosis. FEBS Lett. 2006, 580, 5533-5540. [CrossRef] [PubMed]

23. El-Faham, A.; Albericio, F. Peptide Coupling Reagents, More than a Letter Soup. Chem. Rev. 2011, 111, 6557-6602. [CrossRef] [PubMed]

24. Dunetz, J.R.; Magano, J.; Weisenburger, G.A. Large-Scale Applications of Amide Coupling Reagents for the Synthesis of Pharmaceuticals. Org. Process. Res. Dev. 2016, 20, 140-177. [CrossRef]

25. Pattabiraman, V.R.; Bode, J.W. Rethinking amide bond synthesis. Nature 2011, 480, 471-479. [CrossRef] [PubMed]

26. Osburn, E.J.; Chau, L.K.; Chen, S.Y.; Collins, N.; OBrien, D.F.; Armstrong, N.R. Novel amphiphilic phthalocyanines: Formation of Langmuir-Blodgett and cast thin films. Langmuir 1996, 12, 4784-4796. [CrossRef]

27. Dong, R.N.; Qiu, Y.; Tian, S.F.; Wang, S.Q.; Song, X.Q. Oxidative biomacromolecular damage from novel phthalocyanine. Sci. China Ser. B 1998, 41, 45-49. [CrossRef]

28. Mikhalenko, S.A.; Solov'eva, L.I.; Luk'yanets, E.A. Phthalocyanines and related compounds: XXXVII. Synthesis of covalent conjugates of carboxy-substituted phthalocyanines with alpha-amino acids. Russ. J. Gen. Chem. 2004, 74, 451-459. [CrossRef]

29. Haywood-Small, S.L.; Vernon, D.I.; Griffiths, J.; Schofield, J.; Brown, S.B. Phthalocyanine-mediated photodynamic therapy induces cell death and a $\mathrm{G}(0) / \mathrm{G}(1)$ cell cycle arrest in cervical cancer cells. Biochem. Biophys. Res. Commun. 2006, 339, 569-576. [CrossRef] [PubMed] 
30. Drechsler, U.; Pfaff, M.; Hanack, M. Synthesis of novel functionalised zinc phthalocyanines applicable in photodynamic therapy. Eur. J. Org. Chem. 1999, 3441-3453. [CrossRef]

31. Sibrian-Vazquez, M.; Ortiz, J.; Nesterova, I.V.; Fernandez-Lazaro, F.; Sastre-Santos, A.; Soper, S.A.; Vicente, M.G.H. Synthesis and properties of cell-targeted $\mathrm{Zn}(\mathrm{II})$-phthalocyanine-peptide conjugates. Bioconjugate Chem. 2007, 18, 410-420. [CrossRef] [PubMed]

32. Ongarora, B.G.; Fontenot, K.R.; Hu, X.K.; Sehgal, I.; Satyanarayana-Jois, S.D.; Vicente, D.G.H. Phthalocyanine-Peptide Conjugates for Epidermal Growth Factor Receptor Targeting. J. Med. Chem. 2012, 55, 3725-3738. [CrossRef] [PubMed]

33. Dubuc, C.; Langlois, R.; Benard, F.; Cauchon, N.; Klarskov, K.; Tone, P.; van Lier, J.E. Targeting gastrin-releasing peptide receptors of prostate cancer cells for photodynamic therapy with a phthalocyanine-bombesin conjugate. Bioorg. Med. Chem. Lett. 2008, 18, 2424-2427. [CrossRef] [PubMed]

34. Ali, H.; Ait-Mohand, S.; Gosselin, S.; van Lier, J.E.; Guerin, B. Phthalocyanine-Peptide Conjugates via Palladium-Catalyzed Cross-Coupling Reactions. J. Org. Chem. 2011, 76, 1887-1890. [CrossRef] [PubMed]

35. Chen, Z.; Zhou, S.Y.; Chen, J.C.; Deng, Y.C.; Luo, Z.P.; Chen, H.W.; Hamblin, M.R.; Huang, M.D. Pentalysine beta-Carbonylphthalocyanine Zinc: An Effective Tumor-Targeting Photosensitizer for Photodynamic Therapy. Chemmedchem 2010, 5, 890-898. [CrossRef] [PubMed]

36. Montalbetti, C.A.G.N.; Falque, V. Amide bond formation and peptide coupling. Tetrahedron 2005, 61, 10827-10852. [CrossRef]

37. Han, S.Y.; Kim, Y.A. Recent development of peptide coupling reagents in organic synthesis. Tetrahedron 2004, 60, 2447-2467. [CrossRef]

38. Schoenberg, A.; Heck, R.F. Palladium-Catalyzed Formylation of Aryl, Heterocyclic, and Vinylic Halides. J. Am. Chem. Soc. 1974, 96, 7761-7764. [CrossRef]

39. Gabriele, B.; Veltri, L.; Mancuso, R.; Carfagna, C. Cascade Reactions: A Multicomponent Approach to Functionalized Indane Derivatives by a Tandem Palladium- Catalyzed Carbamoylation/Carbocylization Process. Adv. Synth. Catal. 2014, 356, 2547-2558. [CrossRef]

40. Veltri, L.; Mancuso, R.; Altomare, A.; Gabriele, B. Divergent Multicomponent Tandem Palladium-Catalyzed Aminocarbonylation-Cyclization Approaches to Functionalized Imidazothiazinones and Imidazothiazoles. ChemCatChem 2015, 7, 2206-2213. [CrossRef]

41. Veltri, L.; Grasso, G.; Rizzi, R.; Mancuso, R.; Gabriele, B. Palladium-Catalyzed Carbonylative Multicomponent Synthesis of Functionalized Benzimidazothiazoles. Asian J. Org. Chem. 2016, 5, 560-567. [CrossRef]

42. Veltri, L.; Giofrè, S.V.; Devo, P.; Romeo, R.; Dobbs, A.P.; Gabriele, B. A Palladium Iodide-Catalyzed Oxidative Aminocarbonylation-Heterocyclization Approach to Functionalized Benzimidazoimidazoles. J. Org. Chem. 2018, 83, 1680-1685. [CrossRef] [PubMed]

43. Gabriele, B.; Mancuso, R.; Salerno, G. Oxidative Carbonylation as a Powerful Tool for the Direct Synthesis of Carbonylated Heterocycles. Eur. J. Org. Chem. 2012, 2012, 6825-6839. [CrossRef]

44. Wu, X.-F.; Neumann, H.; Beller, M. Synthesis of Heterocycles via Palladium-Catalyzed Carbonylations. Chem. Rev. 2013, 113, 1-35. [CrossRef] [PubMed]

45. Wu, X.-F.; Neumann, H.; Beller, M. Palladium-Catalyzed Oxidative Carbonylation Reactions. Chemsuschem 2013, 6, 229-241. [CrossRef] [PubMed]

46. Gadge, S.T.; Bhanage, B.M. Recent developments in palladium catalysed carbonylation reactions. RSC Adv. 2014, 4, 10367-10389. [CrossRef]

47. Wu, L.; Fang, X.; Liu, Q.; Jackstell, R.; Beller, M.; Wu, X.-F. Palladium-Catalyzed Carbonylative Transformation of C(sp3)-X Bonds. ACS Catal. 2014, 4, 2977-2989. [CrossRef]

48. Kalck, P.; Urrutigoïty, M. Recent improvements in the alkoxycarbonylation reaction catalyzed by transition metal complexes. Inorg. Chim. Acta 2015, 431, 110-121. [CrossRef]

49. Wu, X.-F. Palladium-catalyzed carbonylative transformation of aryl chlorides and aryl tosylates. RSC Adv. 2016, 6, 83831-83837. [CrossRef]

50. Shen, C.; Wu, X.-F. Palladium-Catalyzed Carbonylative Multicomponent Reactions. Chem.A Eur. J. 2017, 23, 2973-2987. [CrossRef] [PubMed]

51. Kollar, L. Modern Carbonylation Methods; Kollar, L., Ed.; Wiley VCH: Weinheim, Germany, 2008.

52. Nemykin, V.N.; Lukyanets, E.A. Synthesis of substituted phthalocyanines. Arkivoc 2010, 136-208. 
53. Yang, S.I.; Li, J.Z.; Cho, H.S.; Kim, D.; Bocian, D.F.; Holten, D.; Lindsey, J.S. Synthesis and excited-state photodynamics of phenylethyne-linked porphyrin-phthalocyanine dyads. J. Mater. Chem. 2000, 10, $283-296$. [CrossRef]

54. Carrilho, R.M.B.; Heguaburu, V.; Schapiro, V.; Pandolfi, E.; Kollar, L.; Pereira, M.M. An efficient route for the synthesis of chiral conduritol-derivative carboxamides via palladium-catalyzed aminocarbonylation of bromocyclohexenetetraols. Tetrahedron 2012, 68, 6935-6940. [CrossRef]

55. Carrilho, R.M.B.; Pereira, M.M.; Takacs, A.; Kollar, L. Systematic study on the catalytic synthesis of unsaturated 2-ketocarboxamides: Palladium-catalyzed double carbonylation of 1-iodocyclohexene. Tetrahedron 2012, 68, 204-207. [CrossRef]

56. Fun, H.K.; Kobkeatthawin, T.; Ruanwas, P.; Chantrapromma, S. (E)-1-(4-Aminophenyl)-3-(2,4,5trimethoxyphenyl)prop-2-en-1-one. Acta Crystallogr. E 2010, 66, O1973-U1802. [CrossRef] [PubMed]

57. Muller, E.; Peczely, G.; Skoda-Foldes, R.; Takacs, E.; Kokotos, G.; Bellis, E.; Kollar, L. Homogeneous catalytic aminocarbonylation of iodoalkenes and iodobenzene with amino acid esters under conventional conditions and in ionic liquids. Tetrahedron 2005, 61, 797-802. [CrossRef]

58. Takacs, A.; Abreu, A.R.; Peixoto, A.F.; Pereira, M.; Kollar, L. Synthesis of Ortho-alkoxy-aryl Carboxamides via Palladium-Catalyzed Aminocarbonylation. Synth. Commun. 2009, 39, 1534-1548. [CrossRef]

59. Li, B.Y.; Zhang, Y.M.; Ma, D.X.; Li, L.; Li, G.H.; Li, G.D.; Shi, Z.; Feng, S.H. A strategy toward constructing a bifunctionalized MOF catalyst: Post-synthetic modification of MOFs on organic ligands and coordinatively unsaturated metal sites. Chem. Commun. 2012, 48, 6151-6153. [CrossRef] [PubMed]

60. Prasad, Y.R.; Rao, A.S.; Rambabu, R. Synthesis of Some 4'-Amino Chalcones and their Antiinflammatory and Antimicrobial Activity. Asian J. Chem. 2009, 21, 907-914.

61. Fang, W.W.; Zhu, H.B.; Deng, Q.Y.; Liu, S.L.; Liu, X.Y.; Shen, Y.J.; Tu, T. Design and Development of Ligands for Palladium-Catalyzed Carbonylation Reactions. Synthesis-Stuttgart 2014, 46, 1689-1708. [CrossRef]

62. De la Fuente, V.; Godard, C.; Claver, C.; Castillon, S. Highly Selective Palladium-Catalysed Aminocarbonylation of Aryl Iodides using a Bulky Diphosphine Ligand. Adv. Synth. Catal. 2012, 354, 1971-1979. [CrossRef]

63. Brennfuhrer, A.; Neumann, H.; Beller, M. Palladium-Catalyzed Carbonylation Reactions of Aryl Halides and Related Compounds. Angew. Chem. Int. Ed. 2009, 48, 4114-4133. [CrossRef] [PubMed]

64. Wu, X.F.; Neumann, H.; Beller, M. Selective Palladium-Catalyzed Aminocarbonylation of Aryl Halides with CO and Ammonia. Chem. Eur. J. 2010, 16, 9750-9753. [CrossRef] [PubMed]

65. Carrilho, R.M.B.; Almeida, A.R.; Kiss, M.; Kollar, L.; Skoda-Foldes, R.; Dabrowski, J.M.; Moreno, M.J.S.M.; Pereira, M.M. One-Step Synthesis of Dicarboxamides through Pd-Catalysed Aminocarbonylation with Diamines as N-Nucleophiles. Eur. J. Org. Chem. 2015, 1840-1847. [CrossRef]

66. Dwyer, D.S.; Bradley, R.J. Chemical properties of alcohols and their protein binding sites. Cell. Mol. Life Sci. 2000, 57, 265-275. [CrossRef] [PubMed]

67. Graton, J.; Besseau, F.; Brossard, A.M.; Charpentier, E.; Deroche, A.; Le Questel, J.Y. Hydrogen-Bond Acidity of $\mathrm{OH}$ Groups in Various Molecular Environments (Phenols, Alcohols, Steroid Derivatives, and Amino Acids Structures): Experimental Measurements and Density Functional Theory Calculations. J. Phys. Chem. A 2013, 117, 13184-13193. [CrossRef] [PubMed]

68. Atilla, D.; Durmus, M.; Gurek, A.G.; Ahsen, V.; Nyokong, T. Synthesis, photophysical and photochemical properties of poly(oxyethylene)-substituted zinc phthalocyanines. Dalton Trans. 2007, 1235-1243. [CrossRef] [PubMed]

69. Sekkat, N.; van den Bergh, H.; Nyokong, T.; Lange, N. Like a Bolt from the Blue: Phthalocyanines in Biomedical Optics. Molecules 2012, 17, 98-144. [CrossRef] [PubMed]

70. Isago, H. Optical Spectra of Phthalocyanines and Related Compounds: A Guide for Beginners; Springer: Tokyo, Japan, 2015.

(C) 2018 by the authors. Licensee MDPI, Basel, Switzerland. This article is an open access article distributed under the terms and conditions of the Creative Commons Attribution (CC BY) license (http:// creativecommons.org/licenses/by/4.0/). 